\title{
The Role and Performance of Bali Cattle Fed Agriculture Waste Product in Integrated Farming System
}

\author{
Mastika IM, Puger AW, Budiasa IKM, Mudita IM \\ Faculty of Animal Husbandry, Udayana University \\ Jl. PB Sudirman, Denpasar 222096, Bali, Indonesia \\ puger.anton@gmail.com
}

\begin{abstract}
A method to increase farmland productivity by integration of Bali cattle to support the family income was carried out. Nine farmers were involved and each of them has 0.5 ha of farmland. A Complete Randomized Block Design with three treatments that with no cattle in their farmland (T0), given one cattle (T1), given two cattles (T2) and three replicates of each treatment were used. Farmland, feed production and cattle growth were used as parameters. The soil condition of land was very poor where the C-organic content $1.25 \%$. Keeping one and two cattles, the system will provide 2,065.9 and 4,677.7 kg manure in one year. Rice crop for T0, T1, and T2 were 3,514; 3,545 and $3,903 \mathrm{~kg}$ per $0.5 \mathrm{ha}$, not significant difference among them. Agricultural waste availability for T0, T1, and T2 were 15,403; 19,966 and 19,946.3 kg. These data suggested that the farmer can increase their cattle number up to 4 head/farmer in 0.5 ha crops land. Feeding agricultural waste supplemented with $1 \mathrm{~kg}$ of rice bran result Bali cattle gain was 0.55-0.56 $\mathrm{kg} / \mathrm{head} / \mathrm{day}$. It was concluded that farm land productivity can be increased by integrating Bali cattle in the crops land area.
\end{abstract}

Key Words: Cattle, Integration, Rice Production, Waste Product

\section{INTRODUCTION}

The constant decreasing of the farm land area in Bali which is reported about 1,000 ha per year is quite disturbing the development of agriculture sector, meaning that Bali will be no longer can provided rice for their people. Based on the Bali province report (Animal and Livestock Service Bali Province 2006), Bali province consisted of 81,207 ha of wet land for rice plantation and 481,650 ha of dry land. The size of the land owned by farmers is also very narrow with the average size 0.30-0.50 ha/farmer (Suparta 2008; Mastika 2008a). All of the above conditions causing agriculture sector is considered not prospective job especially for the younger generation, because it is not efficient anymore as an income resource for farmer family. This will have a significant impact on agriculture development program in Bali and other islands with dense population, and there is a tendency that the land owner want to sell their farm land for housing or other purposes became is not economically sound anymore as source of income of the farmer family. This condition is quite true in Badung, Gianyar Districts and in Denpasar manucipality. Similarly, the Bali condition of farming also occure in Java, Madura even in some Asian countries like Bangladesh, Phillipines where farming is not promising any more to support the family income for the welfare of the most farmers family.

However, when we look carefully, there is another space available as an effort to increase farmers income that is by integrated farming system (Mastika 2008a), where farmer will get rice as the main product from farming and they also can get some additional income if the farmers fatten Bali cattle 2 up to 3 cattles/farmers and kept it in their farming areas. As stated by Mastika (2003) that the mayor constraints for animal production in Eastern part of Indonesia is availability of feedstuff both quality and quantity. On the other hand, rice straw production is abundant and this fibrous feed stuff is 
not optimal utilized due to the fact that the farmers are used to feed their cattle with fresh green forage. With the present technology available, the quality of rice straw can be improved by chemicals, physical and biofermentation process (Preston \& Leng 1987). It was stated that the simplest process of improving rice straw quality by urea fermentation process. Urea fermentation of rice straw can be increase digestibility of this fibrous feed from $30-40 \%$ to $45-55 \%$ (Sundstol \& Owen 1984). This integrated model will also help the farmers to improve their farm soil condition through additional cattle manure and urine which is very good for additional organic matter, as well as reducing the used of anorganic fertilizersthus reducing farm expenses (Orskov 1993). Those concept, partly was applied to improve farmers income in SubakGuama, Batan Nyuh and Peken Villages, Tabanan District, Province of Bali by Agricultural Services Office, Province of Bali as demonstration plot (Sudiksa 2002a; 2002b) which called CLS-ICM Project, but this pilot project is not working on crop and animal production efficiency, but calculate and include all farmers family activities insteadas an effort to increase the family income. Base on this condition, an experiment was carried out to study the method of increasing farm land productivity by integration of Bali cattle in the farming area.

\section{MATERIAL AND METHODS}

\section{Location/site of the experiment}

The experiment was carried out at Penglatan Village, Buleleng Districts North of Bali. A total of nine farmers each of them have 0.45-0.55 ha of farm land was used in this experiment. They were divided into three groups namely: Group 1-farm land without cattle in it (T0); Group 2-farm land with one cattle inside the farm land (T1); and the last group where farm land with two cattles inside the farm area (T2).

\section{Bali cattle used in this experiment}

Nine farmers are involved and each of them has 0.5 ha of farmland. A Complete Randomized Block Design with three treatments and three replicates of each treatment were used. A total of nine Bali cattle bulls belong to the farmers were hired for the experiment and each of farmers was given an incentive to improve the condition of its cattle barns. Body weight of the cattle used in this experiment was between 180 to $200 \mathrm{~kg}$ which considered as suitable body weight for fattening of Bali cattle. Bali cattle were randomly assigned and placed in farm land either one cattle per 0.5 ha farm land for $\mathrm{T} 1$ and two cattles per 0.5 ha farm land for $\mathrm{T} 2$, and land without cattle (T0) is used as control.

\section{Feeds and feeding}

All cattle were housed all the time in barn so the faeces is easily to be collected as source of organic fertilizer. The cattle were fed grasses and legumes that produced and grown around the farm area and were given supplementation one $\mathrm{kg}$ of rice bran per head per day. Rice bran is produced and taken from the farm land, so practically there is no feed given to the cattle from outside of the farm. Forage and water were provided ad libitum. As anticipated the depletion of green forage during dry season, farmer are also taught to use fermented rice straw. Farmers were given one day course and practical work in preparing and making fermented rice straw using urea as fermenting agent. This method will help feeding cattle during dry season and also their cattle will get a better quality of feed. Feeding urea fermented rice straw and with small amount of green forage can 
significantly improve the cattle performance (Preston \& Leng 1987; Nitis 1992). In order to get and understand the growth performance of the cattle, all cattle were weighed every month. Feed consumption were also measured and recorded by subtracting the feed given and the feed refused at the following day. Manure (fresh) were sampled in seven days per month to get the data on fresh manure production. Fresh manure then dried under the sun then dry manure can be calculated for the estimation of organic fertilizer production in a year.

\section{Soil conditions measurement}

Before the experiment is started the soil samples were collected from nine site of farm land and brought to the soil laboratory (Faculty of Agriculture) for soil analysis. Parameters measured are $\mathrm{pH}$, organic matter, nitrogen. phosphor, potassium content of the soil, water holding capacity, and texture of the soil.

\section{Duration of experiment}

The experiment was carried out in 10 months period. Data collections on farm production were run for two periods that is the first four months (Kertamasa meaning rice season, first planting in the year for February-May) and the second four months (MaySeptember) where the water for farm land is decreasing in quantity (Gadon meaning mix rice or horticulture). During these two periods samples for green forage production as well as rice straw production for animal feeds were measured so from that data estimation of feed production per year can be determined.

\section{Farm productivity}

The farm land production or productivity were measured using some criteria such as number of stumps per 0.50 ha. Number of tillers in one stump, rough rice production, rice and bran production. For animal feed, rice straw, green forage are also measured. Cattles performances were measured by weighing the cattle every month so the weight gain in a period or daily gain can be calculated. The faecesas source of organic fertilizer was measured in seven consecutive days for every months, so production of fresh manure can be determined.

\section{Data analysis}

All data collected were tabulated and analyzed using analysis of variance (Chang 1972) if significant followed by Duncan Test.

\section{RESULTS AND DISCUSSION}

As stated by Nielsen \& Preston (1984) that the integrated farming system is a set of biological processes and management activities organized with the available resources to produced plant and animal products for food consumption. In this experiment biological processes with rice plantation and bali cattle production and management activities such as integration, of two activities rice plantation and fattened Bali cattle were carried out simultaneously and this activities then organized with land resource in order to produce animal feeds (green forage and agricultural waste as well as the cattle droppings for organic fertilizer). The final goal of this system is to provide plant and animal products for food or to increase the welfare of the farmers. From the results of Laboratory analysis, the 
soil conditions of all samples taken from nine sites, the $\mathrm{C}$-organic, and $\mathrm{N}$-total was far below the standard soil for rice (Table 1).

The C-organic was below 2\% (average 1.256\%). Nitrogen content (total) of the soil from the nine sites (total) of experimental farm was below $0.21 \%$ (average $0.132 \%$ ) (standard 0.21-0.75\%). On the contrary, phosphor content for all sites was higher than the standard for rice (16-35\%). From those data available it was logical that the land production in that area below the expectation of Agricultural Service Office of Bali. This was partly due to the fact,that the C-organic content below $2 \%$ which is called the soil was in the sick condition and the nitrogen content also below the standard.

Table 1. Soil condition of farm land before experiment was started

\begin{tabular}{lrrrrc}
\hline \hline \multirow{2}{*}{ Variables } & \multicolumn{3}{c}{ Treatments } & \multirow{2}{*}{ SEM } & Standard for rice \\
\cline { 2 - 4 } & \multicolumn{1}{c}{$\mathrm{T} 0$} & \multicolumn{1}{c}{$\mathrm{T} 1$} & \multicolumn{1}{c}{$\mathrm{T} 2$} & & \\
\hline $\mathrm{pH}$ & 6.3 & 6.1 & 6.2 & 0.150 & $5.60-7.00$ \\
Carbon organic (\%) & 1.380 & 1.517 & 0.870 & 0.237 & $2.00-5.00$ \\
N total (\%) & 0.117 & 0.150 & 0.130 & 0.019 & $0.21-0.75$ \\
P available (\%) & 36.407 & 67.820 & 21.923 & 18.322 & $16.00-35.00$ \\
K available (\%) & 85.033 & 256.877 & 261.587 & 63.103 & $156.00-390.00$ \\
Texture (\%) & & & & & \\
$\quad$ Sand & 38.870 & 35.523 & 30.603 & 1.913 & \\
Silt & 36.230 & 35.660 & 39.630 & 1.686 & \\
$\quad$ Clay & 25.897 & 28.820 & 29.767 & 1.319 & \\
\hline
\end{tabular}

T0: Without cattle; T1: One cattle; T2: Two cattles for 0.5 ha farm land

Source: Soil Laboratory, Faculty of Agriculture, Udayana University

During the experimental period in twice harvesting of rice production (Table 2) of rough rice of farm land without cattle (T0) was recorded $5,412 \mathrm{~kg}$, for those with one cattle in the farm land (T1) was $5,629 \mathrm{~kg}$ and that was $4 \%$ higher than $\mathrm{T} 0$ although not significant. The trend increased of rough rice production was in T2 that was $6,578 \mathrm{~kg}$. This figure is about $21.54 \%$ higher than those without cattle (T0). The similar trend was observed in rice (polished) production. It was recorded that rice production for $\mathrm{T} 0, \mathrm{~T} 1$ and $\mathrm{T} 2$ were 3,$514 ; 3,545$; and $3,903 \mathrm{~kg}$. When it was compared to $\mathrm{T} 0$ (control), rice production of $\mathrm{T} 1$ and $\mathrm{T} 2$ has increased 0.88 and $11 \%$ higher.

Table 2. Rice plant performance, production of rice and its by products of farm lands with or without Bali cattle during the period of the experiment

\begin{tabular}{lrrrr}
\hline \hline \multirow{2}{*}{ Variables (in 0.5 ha) } & \multicolumn{3}{c}{ Treatments } & \multirow{2}{*}{ SEM } \\
\cline { 2 - 4 } & \multicolumn{1}{c}{ T0 } & \multicolumn{1}{c}{ T1 } & \multicolumn{1}{c}{ T2 } & \\
\hline Number of stumps & $86,400.0$ & $98,400.0$ & $101,333.0$ & 42.06 \\
Number of tillers/stump & 28.7 & 29.3 & 31.2 & 3.72 \\
Rough rice production (kg) & $5,412.0$ & $5,629.0$ & $6,578.0$ & 640.41 \\
Empty seed production (kg) & 445.3 & 693.4 & 648.0 & 121.38 \\
Rice straw production (kg) & $13,892.7$ & $15,400.7$ & $15,808.0$ & $1,823.97$ \\
Rice (polished) production (kg) & $3,514.0$ & $3,545.0$ & $3,903.0$ & 415.06 \\
Rice bran production (kg) & 573.1 & 646.1 & 758.3 & 87.84 \\
Rice hulls production (kg) & 937.8 & 900.9 & 1212.5 & 71.94 \\
\hline
\end{tabular}

T0: Without cattle; T1: One cattle; T2: Two cattles for 0.5 ha farm land 
As stated by Sudiksa (2002a; 2002b ) that the rice crop land in Bali is in the state of sick conditions, after almost 32 years the land was forced for increasing production using chemicals fertilizer only without additional of organic fertilizer. With the integrated system (integration with one or two cattle per 0.5 ha of farm land) that sick condition will be gradually improved by the addition of organic manure from the cattle (Table 3). By this system, 2-4.5 ton of organic manure can be expected and available in a year.

The present result (Table 3) suggested feeding Bali cattle with crops residues and supplementation $1 \mathrm{~kg}$ of rice bran gave roughly $0.5 \mathrm{~kg}$ daily gain and the farmers have sufficient feed stuffs for their cattle from their own land only. This is in line with the report of Mastika (2003) that supplementation of good concentrated (rice bran) is needed for Bali cattle to achieve $0.5 \mathrm{~kg}$ daily gain.

Table 3. Daily gain, feed consumption and feces produced in integrated farming system

\begin{tabular}{lrr}
\hline \hline Parameters & \multicolumn{1}{c}{ T1 } & \multicolumn{1}{c}{ T2 } \\
\hline Daily gain/head $(\mathrm{g})$ & 558.10 & 547.10 \\
Feed consumption (1 kg rice bran + green forage) (kg/head/day) & 29.42 & 28.34 \\
Rice bran + green fodder (kg) & 1.00 & 1.00 \\
Rice straw (kg) & 28.42 & 27.34 \\
Fresh feces production (kg/head/day) & 11.33 & 12.78 \\
Feces air dry weight production (kg/head/day) & 5.66 & 6.39 \\
Feces air dry weight production per year (365 days ) $(\mathrm{kg})$ & $2,065.90$ & $4,664.70$ \\
\hline
\end{tabular}

T1: One cattle; T2: Two cattles for 0.5 ha farm land

Considering that Bali cattle with the average weight $250 \mathrm{~kg} / \mathrm{head}$, they needs feed about $3.5 \%$ of body weight of feed per day, so in one year they will consumed about 7.5$10.5 \mathrm{~kg} \times 365$ days $=2,737.5-3,832.5 \mathrm{~kg}$ of feed. Excluding the rice straw utilization as feed improvement, the production of green forage and rice bran only (Table 4) for T1 and $\mathrm{T} 2$ was $4,565.7 \mathrm{~kg}$ and $4,138.27 \mathrm{~kg}$ respectively; meaning that the farmers can raise cattle 1 up to 1.5 cattle without taking feed from outside their farm area. With the rice straw production between 15.4-15.8 ton (Table 4); theoretically the number of cattle can be increased up to 4-5 cattle per 0.5 ha farm land without afraid of feed shortage. This must be followed by processing technology for rice straw to increase the quality of the waste product. The simplest method commonly used and could be easily applied in tropical conditions to increase rice straw quality is urea fermentation technology (Nicholson 1984; Leng 1982).

Table 4. Feed availability for cattle for eight months period from the farm land

\begin{tabular}{lrrrr}
\hline \hline \multirow{2}{*}{ Variables (kg DW/0.5 ha) } & \multicolumn{3}{c}{ Treatments } & \multirow{2}{*}{ SEM } \\
\cline { 2 - 4 } & \multicolumn{1}{c}{ T0 } & \multicolumn{1}{c}{ T1 } & \multicolumn{1}{c}{ T2 } & \\
\hline Rice straw production & $13,892.70$ & $15,400.70$ & $15,808.00$ & $1,823.97$ \\
Rice bran production & 573.10 & 646.10 & 758.30 & 87.84 \\
Grass production & $455.86^{\mathrm{a}}$ & $3,578.40^{\mathrm{b}}$ & $3,176.17^{\mathrm{b}}$ & 244.79 \\
Legume production & 481.60 & 341.20 & 203.80 & 168.10 \\
\hline Total & $15,403.26$ & $19,966.40$ & $19,946.27$ & \\
\hline
\end{tabular}

T0: Without cattle; T1: One cattle; T2: Two cattles for 0.5 ha farm land; Value in the same row with different letter is significant $(\mathrm{P}<0.05)$ 
Preston \& Leng (1987) recommended that in tropical condition improvement of rice straw digestibility by urea fermentation was more applicable and the digestibility of rice straw can be increasedfrom $30-40 \%$ up to $45-55 \%$. This technology therefore, will support the concep of providing continuous quantity feed for the whole year from their own land only. In order to increase the gross income of the farmer, they have to learn and addopt the technology and applied it for their cattle so the wellfare of the farmer family can be achieved by integrated farming system and by seriously work on their farm only. At present, abundant of fibrous waste materials available such as rice straw under utilized for animal and its quality can be imroved by chemical, physical and bio technology means. Fermentation of cocoa waste using Aspergillus niger for example, has been reported significantly decreased its fibre content (Mastika 2006; 2007). Farmer in Bali usually feeding their cattle with fresh green forage and as we understand that green forage production is very limted due the fact that land area is limited; and the most important things is the green forage production depend on climate factor to provide sufficient water supplay. All this conditions make the farmers difficult to feed their cattle or increase the number of their cattle (Mastika 2008b). The overall factors resulting in a condition that the farmer family income is low especially in limited farm area. Introducing integrated farming system will therefore improved the family income by addtional cash from selling cattle.

\section{CONCLUSION}

It was concluded that grass production can be increased by integrating Bali cattle in the crops land area.

\section{ACKNOWLEDGEMENT}

The authors wishes to thank to the Government of Republic of Indonesia trough Lemlit of Udayana University who providedfund for this experiment. Thank are due to the head of Department of Animal and Livestock Services for providing the scale for the cattle weight measurement. Any help from the head of the village and administrator, to all farmers who involved in his experiment are acknowledged.

\section{REFERENCES}

Animal and Livestock Service Bali Province. 2006. Informasi data Peternakan Provinsi Bali. Denpasar (Indonesia): Animal and Livestock Service Bali Province.

Chang LC. 1972. The concept of statistics in connection with experimentation. Taipei (Taiwan): Food and Fertilizer Technology Centre.

Leng. 1982. Modification of rumen fermentation. In: hacker JB, editor. Nutritional Limits to Animal Production from Pasture. Proceeding International Symposium. Queensland, 24-28 August 1981. Queensland (Australia): Commonwealth Agricultural Bureaux.

Mastika IM. 2003. Feeding strategies to improve the productions, performance and meat quality of Bali cattle (Bos sondaicus). Proceedings No. 110. Canberra (AUS): ACIAR.

Mastika IM. 2006. Pengolahan limbah kakao sebagai pakan ternak alternatif untuk pakan sapi Bali. Laporan akhir demplot pengendalian hama PBK pada buah kakao dalam pola integrasi. Denpasar (Indonesia): Dinas Perkebunan Provinsi Bali dan HPT Faperta, UNUD. 
Mastika IM. 2007. Pengolahan limbah perkebunan kakao dan potensinya untuk makanan ternak. Laporan akhir Dinas Perkebunan Provinsi Bali dengan Fakultas Pertanian Universitas Udayana. Denpasar (Indonesia): Dinas Perkebunan Provinsi Bali dan HPT Faperta, UNUD.

Mastika IM. 2008a. Kondisi pertanian di Indonesia umumnya dan di Bali khususnya serta permasalahannya. Denpasar (Indonesia): Universitas Udayana.

Mastika IM. 2008b. Penggunaan cangkang kakao yang difermentasi sebanyak 50\% sebagai bahan penyusun konsentrat untuk sapi Bali. Laporan akhir Dinas Perkebunan Provinsi Bali dengan Fakultas Pertanian Universitas Udayana. Denpasar (Indonesia): Dinas Perkebunan Provinsi Bali dan HPT Faperta, UNUD.

Nicholson JWG. 1984. Digestibility, nutritive value and feed intake. In: Straw and fibrous by products as feed. Sundstol F, Owens EC, editors. Rome (Italy): FAO.

Nielsen JJ, Preston JR. 1984. The integrated family farm system for agriculture, livestock and energy production. Project program for the integrated family farm system in Bangladesh for the year (1982-1986).

Nitis IM. 1992. Hijauan limbah pertanian dan limbah industri pertanian untuk makanan ternak ruminansia di wilayah ASEAN. Material for the short course: Recycling of agricultural and agroindustrial by product and waste for animal feed and environmental sanitation. IAEUP Project.

Orskov ER. 1993. Reality in rural development aid with emphasis in livestock. Aberdeen (UK): Roweit Research Service Ltd.

Preston TR, Leng RA. 1987. Matching ruminant production system with available resources in the tropics and sub tropics. Armidale (AUS): Penambul Books.

Sudiksa N. 2002a. Laporan evaluasi integrated crop management (ICM). Bagian proyek pengembangan padi terpadu. Denpasar (Indonesia): Dinas Pertanian Tanaman pangan Provinsi Bali.

Sudiksa N. 2002b. Laporan pelaksanaan and on participatory rural appraisal (PRA) crop livestock system (CLS) di Kecamatan Marga, Kabupaten Tabanan. Denpasar (Indonesia): Dinas Pertanian Tanaman Pangan Provinsi Bali.

Sundstol F, Owen EC. 1984. Ammonia treatment. In: Traw and other fibrus by-product as feed. Amsterdam (Netherlands): Elsevier.

Suparta IN. 2008. Strategi pengelolaan pertanian guna mewujudkan kemandirian dan ketahanan pangan nasional. Dalam: Simposium Pertanian dalam Arti Luas. Denpasar, 20 September 2008. Denpasar (Indonesia): UNUD. 